\title{
Plant regeneration via direct somatic embryogenesis from leaf explants of Tolumnia Louise Elmore 'Elsa'
}

\author{
Hui-Ju Shen ${ }^{1}$, Jen-Tsung Chen ${ }^{2}$, Hsiao-Hang Chung ${ }^{3^{*}}$ (1) and Wei-Chin Chang ${ }^{1}$
}

\begin{abstract}
Background: Tolumnia genus (equitant Oncidium) is a group of small orchids with vivid flower color. Thousands of hybrids have been registered on Royal Horticulture Society and showed great potential for ornamental plant market. The aim of this study is to establish an efficient method for in vitro propagation.

Results: Leaf explants taken from in vitro-grown plants were used to induce direct somatic embryogenesis on a modified 1/2 MS medium supplemented with five kinds of cytokinins, 2iP, BA, kinetin, TDZ and zeatin at 0.3, 1 and $3 \mathrm{mg} \mathrm{I}^{-1}$ in darkness. TDZ at $3 \mathrm{mg} \mathrm{I}^{-1}$ gave the highest percentage of explants with somatic globular embryos after 90 days of culture. It was found that 2,4-D and light regime highly retarded direct somatic embryogenesis and showed $95-100 \%$ of explant browning. Histological observations revealed that the leaf cells divided into meristematic cells firstly, followed by somatic proembryos, and then somatic globular embryos. Eventually, somatic embryos developed a bipolar structure with the shoot apical meristem and the root meristem. Scanning electron microscopy observations showed that the direct somatic embryogenesis from leaf explants was asynchronously. The somatic embryos were found on the leaf tip, the adaxial surface and also the mesophyll through a cleft, and it reflected the heterogeneity of the explant. The 90-day-old globular embryos were detached from the parent explants and transferred onto a hormone-free 1/2 MS medium in light condition for about 1 month to obtain 1-cm-height plantlets. After another 3 months for growth, the plantlets were potted with Sphagnum moss and were acclimatized in a shaded greenhouse. After 1 month of culture, the survival rate was 100\%.
\end{abstract}

Conclusions: In this report, a protocol for efficient regenerating a Tolumnia orchid, Louise Elmore 'Elsa', was established via direct somatic embryogenesis and might reveal an alternative approach for mass propagation of Tolumnia genus in orchid industry.

Keywords: Cytokinin, Direct somatic embryogenesis, Leaf explant, Light regime

\section{Background}

Tolumnia, previously referred to as "the equitant oncidiums", is small and epiphytic with unapparent pseudobulbs that usually covered by leaves. The leaves arranged in pairs overlapping or straddling one another at the base. In cross section, the leaves showed circular or triangular shape. The inflorescence of Tolumnia orchids bears attractive and colorful flowers with large labella, and

\footnotetext{
*Correspondence: hhchung@niu.edu.tw

${ }^{3}$ Department of Horticulture, National Ilan University, Yilan 260, Taiwan, ROC

Full list of author information is available at the end of the article
}

therefore became a popular pot plants in flower market worldwide. Based on our knowledge, there was no reliable protocol had been published for propagating Tolumnia in vitro.

In recent years, plant regeneration via direct somatic embryogenesis had been successfully established in various orchids including Dendrobium (Chung et al. 2005), Epipactis (Moradi et al. 2017), Malaxis (Mahendran and Bai 2016), Phalaenopsis (Chen and Chang 2006; Gow et al. 2010; Feng and Chen 2014), Rhynchostylis (Islam and Bhattacharjee 2015) and also a Tolumnia related genus, Oncidium (Chen et al. 1999; Chen and Chang 
2002; Su et al. 2006; Hong et al. 2008a, b). In these previous studies, cytokinins, especially thidiazuron, were found to be effective to induce direct somatic embryogenesis from the leaf explants (Chen et al. 1999; Chen and Chang 2002; Su et al. 2006; Hong et al. 2008a, b). Therefore, to establish an efficient method for regenerating Tolumnia orchids, leaf explants taken from a popular cultivar, Louise Elmore 'Elsa', was used to test the effects of cytokinins on direct somatic embryo formation.

\section{Methods}

\section{Plant materials}

In vitro grown plants of Tolumnia Louise Elmore 'Elsa' were purchased from Taida Horticultural Co. Ltd., Chunghua County, Taiwan. These plants were maintained on a hormone-free 1/2 MS (Murashige and Skoog 1962) medium with sucrose $\left(20 \mathrm{~g} \mathrm{l}^{-1}\right)$ and Gelrite $\left(2.4 \mathrm{~g} \mathrm{l}^{-1}\right)$ at $\mathrm{pH} 5.2 \mathrm{in} 250 \mathrm{ml}$ flasks and subcultured every 2 months period. All of the cultures were incubated under a 16/8-h (light/dark) photoperiod at irradiance of $28-36 \mu \mathrm{mol} \mathrm{m} \mathrm{m}^{-2} \mathrm{~s}^{-1}$ (daylight fluorescent tubes FL-30D/29, 40 W, China Electric Co., Taipei, Taiwan) and temperature of $26 \pm 1{ }^{\circ} \mathrm{C}$. Plants with several roots and leaves (about $2-4 \mathrm{~cm}$ in height) were used as donor plants.

\section{Embryo induction}

The basal medium for embryo induction is a modified MS medium containing 1/2-strength macro- and fullstrength micro-elements of MS salts supplemented with $\left[\mathrm{mg} \mathrm{l}^{-1}\right.$ ]: myo-inositol (100), niacin (0.5), pyridoxine $\mathrm{HCl}$ (0.5), thiamine $\mathrm{HCl}(0.1)$, glycine (2.0), peptone (1000), $\mathrm{NaH}_{2} \mathrm{PO}_{4}(170)$, sucrose $(20,000)$ and Gelrite $(2400)$. The $\mathrm{pH}$ of the media was adjusted to 5.2 with $1 \mathrm{M} \mathrm{KOH}$ or $\mathrm{HCl}$ prior to autoclaving at $121{ }^{\circ} \mathrm{C}$ for $15 \mathrm{~min}$. One-yearold in vitro grown plants of Tolumnia Louise Elmore 'Elsa' were utilized as donor plantlets. Leaf tip segments (about $10 \mathrm{~mm}$ in length) excised from the top first leaves of donor plantlets were used to induce direct somatic embryogenesis on different media supplemented with five cytokinins, 2ip, BA, kinetin, zeatin and thidiazuron (TDZ) at $0,0.3,1$ or $3 \mathrm{mg} \mathrm{l}^{-1}, 2,4-\mathrm{D}\left(0,1,3 \mathrm{mg} \mathrm{l}^{-1}\right)$ combined with $\operatorname{TDZ}\left(0,0.3,1,3 \mathrm{mg} \mathrm{l}^{-1}\right)$. The leaf explants were placed on the culture and incubated in $90 \times 15 \mathrm{~mm}^{2}$ Petri dishes under darkness or a light condition at irradiance of $28-36 \mu \mathrm{mol} \mathrm{m}^{-2} \mathrm{~s}^{-1}$ as mention above in an incubator at temperature of $26 \pm 1{ }^{\circ} \mathrm{C}$.

\section{Plantlet development}

Plantlets derived from somatic embryos with 3-4 leaves were transferred onto a hormone-free $1 / 2 \mathrm{MS}$ medium with sucrose $\left(20 \mathrm{~g} \mathrm{l}^{-1}\right)$ and Gelrite $\left(2.4 \mathrm{~g} \mathrm{l}^{-1}\right)$ in $250 \mathrm{ml}$ flasks with a 1-months-interval subculture period. All of the cultures were incubated under a light condition with 16/8-h (light/dark) photoperiod at irradiance of $28-36 \mu \mathrm{mol} \mathrm{m}{ }^{-2} \mathrm{~s}^{-1}$ and temperature of $26 \pm 1{ }^{\circ} \mathrm{C}$ for further development. After 2 months of culture, the plantlets were transferred into plastic pots with Sphagnum moss in a shaded greenhouse for the further growth.

\section{Histological analysis}

The tissue samples for histological observations were fixed in FAA (95\% ethyl alcohol:glacial acetic acid:formaldehyde:water, 10:1:2:7) for $48 \mathrm{~h}$ and dehydrated in a tertiary-butyl-alcohol series (Liao and Wu 2011). Tissue samples were then infiltrated by liquid paraffin in the oven at $65{ }^{\circ} \mathrm{C}$ and embedded in paraffin wax. The wax blocks containing tissue samples were sectioned to a thickness of $10 \mu \mathrm{m}$ using a Leica RM2125 RTS rotary microtome (Leica Microsystems) and stained with $0.5 \%$ safranin-O (SigmaAldrich Inc., USA) followed by $0.1 \%$ fast green (SigmaAldrich Inc., USA) (Jensen 1962). After staining, sections were permanently mounted on slides for observation.

\section{Scanning electron microscopy (SEM) observations}

Samples for SEM were fixed in $2.5 \%$ glutaraldehyde in $0.1 \mathrm{M}$ phosphate buffer $(\mathrm{pH} 7.0)$ for $4 \mathrm{~h}$ at $4{ }^{\circ} \mathrm{C}$, and then dehydrated in ethanol (Dawes 1971), dried using a critical point dryer (HCP-2, Hitachi), and coated with gold in an ion coater (IB-2, Giko Engineering Co.). A SEM (DSM950, Carl Zeiss) was used for examination and photography of the specimens.

\section{Data analysis}

All the experiments were designed with a randomized complete block design. The percentages of explants forming somatic proembryos (smaller than $0.5 \mathrm{~mm}$ in diameter) and somatic globular embryos (larger than $0.5 \mathrm{~mm}$ in diameter) were counted under a stereomicroscope ( $\mathrm{SZH}$, Olympus, Tokyo, Japan). Data were scored after 75 and 90 days of culture. Five replicates (dishes) and each with four leaf explants were provided for each treatment. The data expressed as percentages were transformed using arc sine prior to ANOVA and then converted back to the original scale (Compton 1994). All treatment means were compared by following Duncan's Multiple Range Test (Duncan 1955). Significant differences between means were presented at the level of $\mathrm{p} \leq 0.05$.

\section{Results and discussion}

The developmental pathway of direct somatic embryogenesis

When the leaf explants were cultured on 1/2 MS medium supplemented with suitable concentrations of cytokinins (the details will be discussed in the following paragraph) for 60 days in darkness, transparent somatic proembryos 
directly formed from the epidermal cells (Fig. 1a) or from the mesophyll cells through a cleft (Fig. 1b). The SEM observations revealed that the size of these somatic proembryos was less than $0.5 \mathrm{~mm}$ in diameter (Fig. 1a, b). After another 15-30 days of culture on the same medium in darkness, some of the somatic proembryos developed into somatic globular embryos that showed whitish to light yellowish in color (Fig. 2a, b). Most of the somatic embryos were found on the leaf tips and the cut ends (Fig. 2a), but less than $10 \%$ of the explants (data not shown) formed somatic embryos from the adaxial sides (Fig. 2b). In general, the size of somatic globular embryos was about $0.5-2 \mathrm{~mm}$ in diameter (Fig. 1a).

\section{Somatic embryo development and plantlet establishment} The 90-day-old somatic globular embryos could be easily detached from the donor leaf explants and transferred

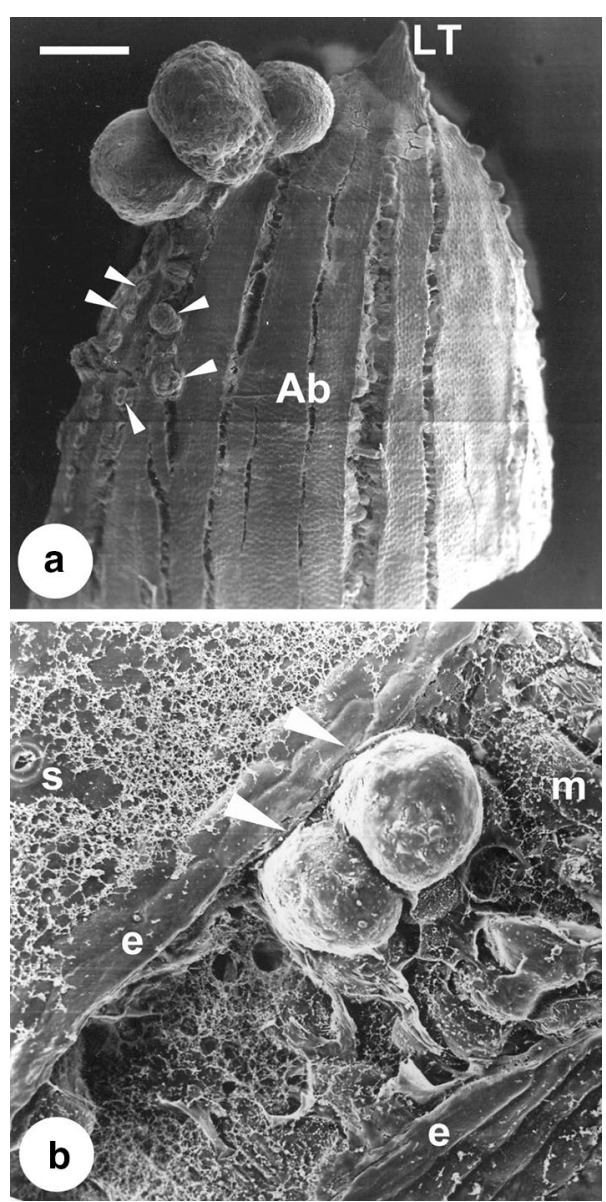

Fig. 1 Scanning electron microscopic observations on direct somatic embryogenesis from leaf explants of Tolumnia Louise Elmore 'Elsa'. a somatic proembryos (SPE, $<0.5 \mathrm{~mm}$ in diameter) and globular embryos ( $\mathrm{SGE},>0.5 \mathrm{~mm}$ in diameter) formed from the leaf cells (Scale bar $1.5 \mathrm{~mm}$ ); b a SPEs formed from the mesophyll cells (Scale bar $100 \mu \mathrm{m})$ onto hormone-free 1/2 MS medium in light condition. After 1-2 weeks of culture, the somatic embryos developed shoots and subsequent turned into 1-cm-height plantlets for another 2 weeks (Fig. 2c). After another 3 months of culture in light condition, morphological normal plantlets were ready to be transplanted into pots with Sphagnum moss (Fig. 2d). Dozens of plantlets were acclimatization in a shaded greenhouse for 1 month, and the survival percentage was $100 \%$ (data not shown).

\section{Histology of somatic embryo development}

The somatic embryos were originated from the meristematic cells of the leaf explants (Fig. 3a). When compared to the original leaf cells, the meristematic cells showed smaller size and obviously densely stained (Fig. 3a). These meristematic cells were divided from the epidermal layers or together with the subepidermal layers of the explants (Fig. 3a). The somatic proembryo developed the typical bipolar structure with the putative shoot apical meristem and the putative root meristem (Fig. 3b). The somatic proembryo could be found on the same explant with the mature embryo, and thus the direct somatic embryogenesis showed an asynchronous behavior (Fig. 3b). On the posterior side of the mature embryos, the cells developed into meristematic cells, and thus suggested that secondary somatic embryogenesis will be in progress (Fig. 3b).

\section{Effects of cytokinins on direct somatic embryogenesis}

Different concentrations of five kinds of cytokinins, 2iP, BA, kinetin, TDZ and zeatin, were tested for their effects on direct somatic embryogenesis (Table 1). After 75 days of culture in darkness, $2 \mathrm{iP}$ at 1 and $3 \mathrm{mg} \mathrm{l}^{-1}$, BA at 1 and $3 \mathrm{mg} \mathrm{l}^{-1}$, TDZ at $0.3,1$ and $3 \mathrm{mg} \mathrm{l}^{-1}$, zeatin at $0.3,1$ and $3 \mathrm{mg} \mathrm{l}^{-1}$ induced the leaf explants to form somatic proembryos (Table 1). The best result was found at $1 \mathrm{mg} \mathrm{l}^{-1}$ zeatin and $65 \%$ of the leaf explants were induced to form somatic proembryos in this treatment (Table 1). In the presence of TDZ at $0.3,1$ and $3 \mathrm{mg} \mathrm{l}^{-1}$, the somatic globular embryos were obtained from the leaf explants (Table 1). Other cytokinins were not able to induce the somatic globular embryos after 75 days of culture in darkness (Table 1). It may partially due to the explant browning that delayed or inhibited the transition from somatic proembryos to globular embryos (Table 1). High browning percentage $(75-100 \%)$ of explants were obtained at the hormone-free control treatment, $0.3,1$ and $3 \mathrm{mg} \mathrm{l}^{-1}$ 2iP and 0.3, 1 and $3 \mathrm{mg} \mathrm{l}^{-1}$ kinetin, and it reflected the relatively lower percentages of somatic embryogenesis from the explants (Table 1). Therefore, these treatments were not suitable for inducing direct somatic embryogenesis (Table 1). 

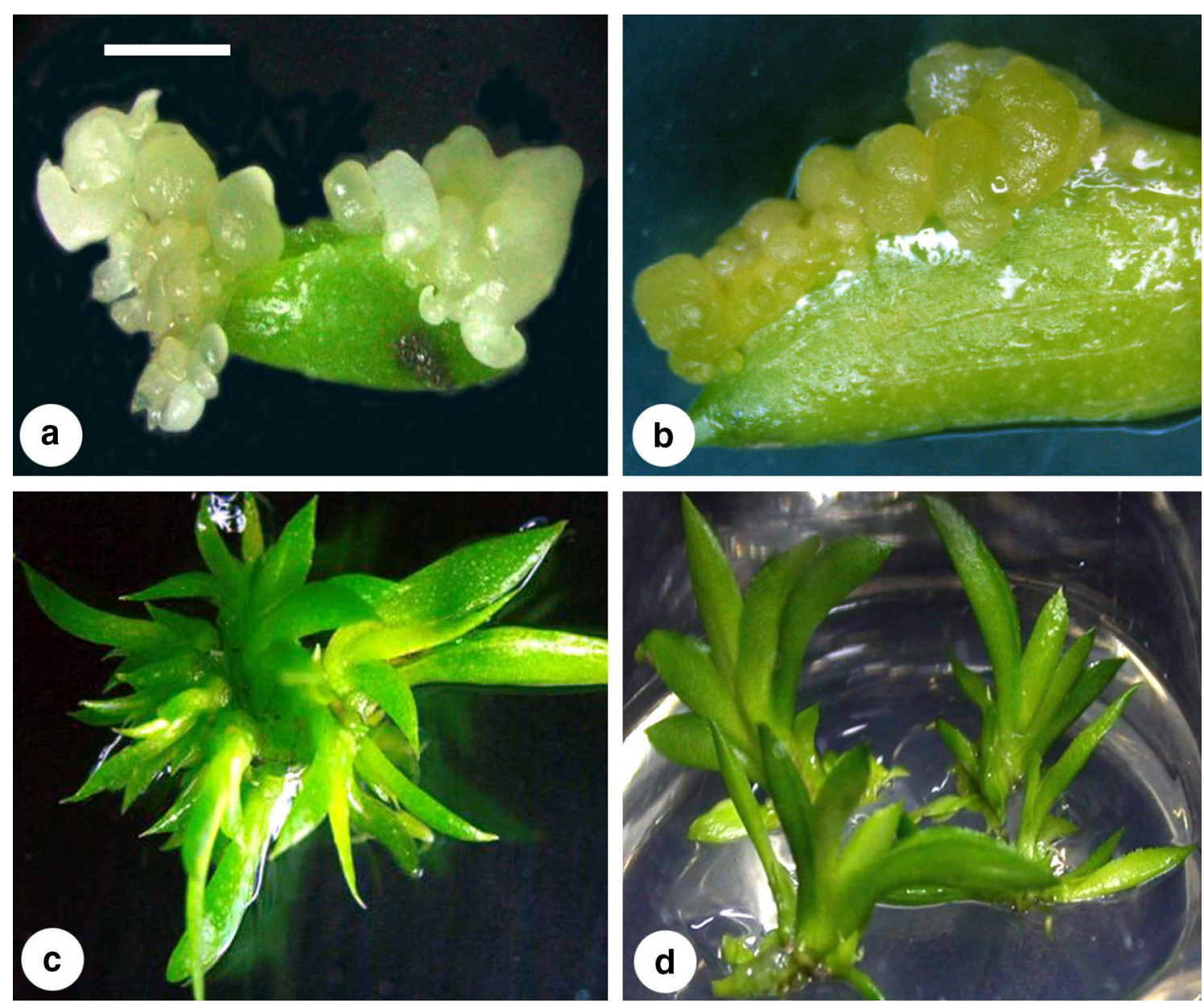

Fig. 2 Somatic embryo development and plant regeneration from leaf explants of Tolumnia Louise Elmore 'Elsa'. a somatic embryos formed on the leaf tip and the cut end of a explant (Scale bar $3.5 \mathrm{~mm}$ ); b somatic embryos formed on the edge of the adaxial surface of the leaf explant (Scale bar $2 \mathrm{~mm}$ ); c multiple shoots developed from leaf-derived somatic embryos (Scale bar $5 \mathrm{~mm}$ ); $\mathbf{d}$ plantlets converted from leaf-derived somatic embryos (Scale bar $2.5 \mathrm{~cm}$ )

After 90 days of culture in darkness, TDZ at 1 and $3 \mathrm{mg} \mathrm{l}^{-1}$, zeatin at $0.3,1$ and $3 \mathrm{mg} \mathrm{l}^{-1}$ induced significantly higher percentages of the leaf explants with somatic proembryos, and TDZ at $3 \mathrm{mg} \mathrm{l}^{-1}$ gave the significantly highest percentages of the leaf explants with somatic globular embryos (Table 2). In the presence of TDZ and zeatin, the browning percentages of explants were lower than $20 \%$, and it reflected the relatively higher percentages of somatic embryogenesis from the explants (Table 2). In a previous report on Oncidium 'Gower Ramsey', a close relative species to Tolumnia, 0.3, 1 and $3 \mathrm{mg} \mathrm{l}^{-1}$ kinetin induced $40 \%$ of the leaf explants to form somatic embryos (Chen and Chang 2001). However, in this present study on the Tolumnia leaf culture, the result showed that kinetin could not induce the direct embryogenesis (Table 2). In the previous report, 1 and $3 \mathrm{mg} \mathrm{l}^{-1}$ TDZ induced $75 \%$ of the leaf explants to form somatic embryos after 40 days of culture in darkness, and it seems these embryos had no boundary to get maturity (Chen and Chang 2001). In this study, although higher percentages of explants with somatic proembryos (75 and 90\%) were induced by 1 and $3 \mathrm{mg} \mathrm{l}^{-1}$ TDZ after 90 days of culture in darkness (Table 2). However, only lower percentages (20 and $35 \%$, respectively) of explants with somatic proembryos got through into somatic globular embryos (Table 2). It was suggested that the timing and requirements of growth regulators on embryo development was vary between the orchid species.

\section{Effects of combinations of 2,4-D and TDZ on direct somatic embryogenesis}

In previous reports, when 2,4-D combined with TDZ at appropriate concentrations, it was effective on embryogenic callus induction in Oncidium (Chen et al. 1999; 

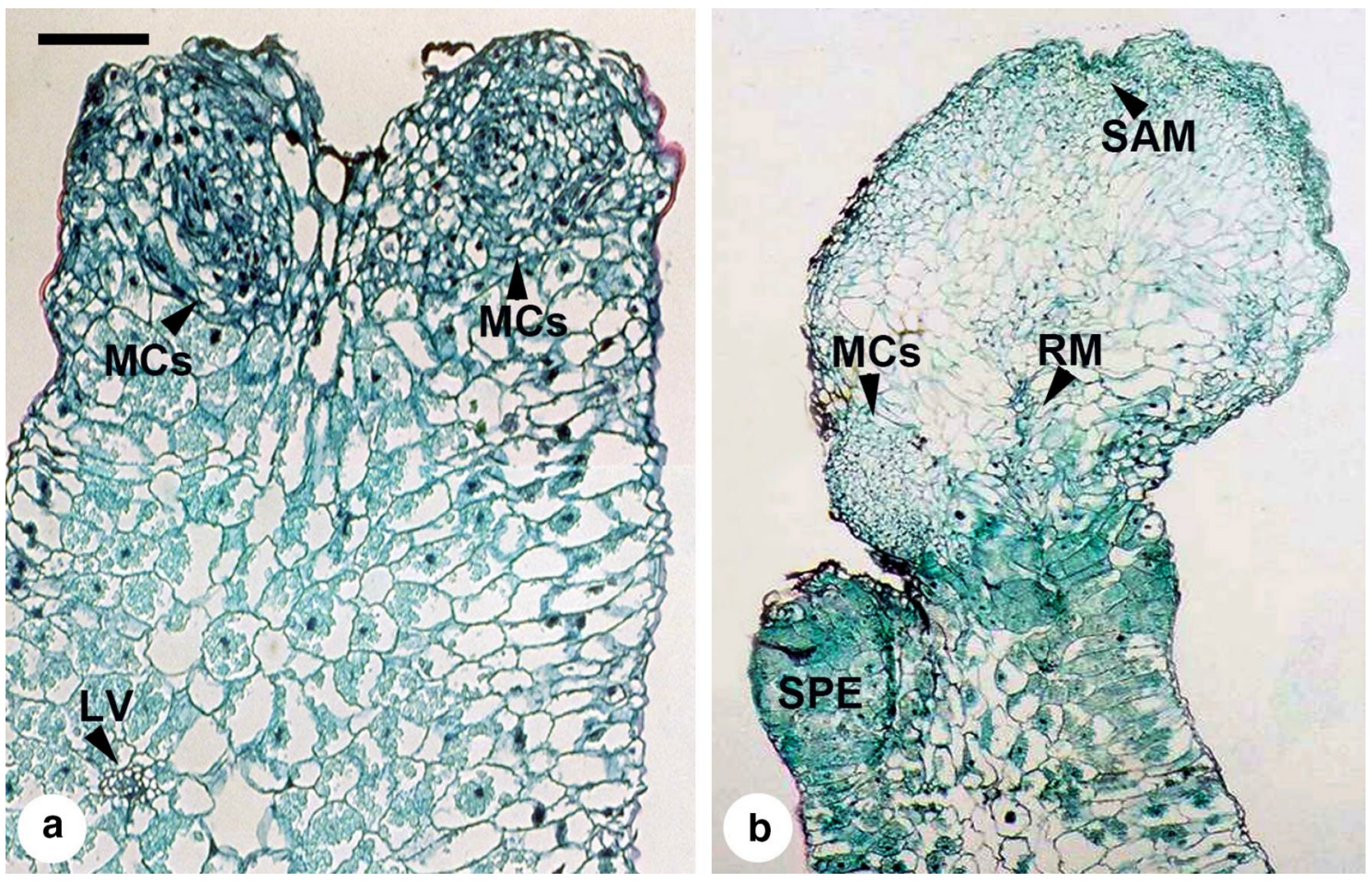

Fig. 3 Histology of direct somatic embryogenesis from leaf explants of Tolumnia Louise Elmore'Elsa'. a meristematic cells (MCs) originated from the mesophyll cells of a leaf explant (Scale bar $0.1 \mathrm{~mm}$ ); leaf vein (LV); b a somatic proembryo (SPE) and a somatic embryo developed the bipolar structure with putative shoot apical meristem (SAM) and putative root meristem (RM) (Scale bar $0.5 \mathrm{~mm}$ )

Table 1 Effects of cytokinins on direct somatic embryogenesis from leaf explants of Tolumnia Louise Elmore 'Elsa', when the explants were cultured in darkness for 75 days

\begin{tabular}{|c|c|c|c|c|}
\hline Cytokinins & Concentration $\left(\mathrm{mg} \mathrm{l}^{-1}\right)$ & $\begin{array}{l}\% \text { of explants } \\
\text { with somatic proembryos }\end{array}$ & $\begin{array}{l}\% \text { of explants } \\
\text { with somatic globular embryos }\end{array}$ & $\%$ of browning \\
\hline Hormone-free control & 0 & $0 f$ & $0 \mathrm{a}$ & $85.0 \mathrm{abc}$ \\
\hline \multirow[t]{3}{*}{ 2iP } & 0.3 & of & $0 \mathrm{a}$ & $90.0 \mathrm{abc}$ \\
\hline & 1 & 20.0 def & $0 \mathrm{a}$ & $75.0 \mathrm{c}$ \\
\hline & 3 & 5.0 ef & $0 \mathrm{a}$ & $80.0 \mathrm{bc}$ \\
\hline \multirow[t]{3}{*}{ BA } & 0.3 & $0 f$ & $0 \mathrm{a}$ & $30.0 \mathrm{~d}$ \\
\hline & 1 & $35.0 \mathrm{abcd}$ & $0 \mathrm{a}$ & $20.0 \mathrm{de}$ \\
\hline & 3 & 15.0 def & $0 \mathrm{a}$ & $10.0 \mathrm{de}$ \\
\hline \multirow[t]{3}{*}{ Kinetin } & 0.3 & of & $0 \mathrm{a}$ & $100.0 \mathrm{a}$ \\
\hline & 1 & $0 f$ & $0 \mathrm{a}$ & $80.0 \mathrm{bc}$ \\
\hline & 3 & of & $0 \mathrm{a}$ & $95.0 \mathrm{ab}$ \\
\hline \multirow[t]{3}{*}{ TDZ } & 0.3 & $50.0 \mathrm{abc}$ & $5.0 \mathrm{a}$ & 5.0 de \\
\hline & 1 & $45.0 \mathrm{abc}$ & $10.0 \mathrm{a}$ & $0 \mathrm{e}$ \\
\hline & 3 & 30.0 bcde & $5.0 \mathrm{a}$ & $10.0 \mathrm{de}$ \\
\hline \multirow[t]{3}{*}{ Zeatin } & 0.3 & $55.0 \mathrm{ab}$ & $0 \mathrm{a}$ & 10.0 de \\
\hline & 1 & $65.0 \mathrm{a}$ & $0 \mathrm{a}$ & 10.0 de \\
\hline & 3 & 30.0 cde & $0 \mathrm{a}$ & $5.0 \mathrm{de}$ \\
\hline
\end{tabular}

Means within a column followed by the same letter are not significantly different according Duncan's multiple range test at $p \leq 0.05$ (Duncan 1955 ) 
Table 2 Effects of cytokinins on direct somatic embryogenesis from leaf explants of Tolumnia Louise Elmore 'Elsa', when the explants were cultured in darkness for 90 days

\begin{tabular}{|c|c|c|c|c|}
\hline Cytokinins & Concentration $\left(\mathrm{mg} \mathrm{l}^{-1}\right)$ & $\begin{array}{l}\% \text { of explants } \\
\text { with somatic proembryos }\end{array}$ & $\begin{array}{l}\% \text { of explants } \\
\text { with somatic globular embryos }\end{array}$ & $\%$ of browning \\
\hline Hormone-free control & 0 & $0 d$ & $0 d$ & $100.0 \mathrm{a}$ \\
\hline \multirow[t]{3}{*}{$2 \mathrm{iP}$} & 0.3 & $0 d$ & $0 d$ & $95.0 \mathrm{ab}$ \\
\hline & 1.0 & $20.0 \mathrm{~cd}$ & $0 d$ & $85.0 \mathrm{ab}$ \\
\hline & 3.0 & $5.0 \mathrm{~d}$ & $0 d$ & $85.0 \mathrm{ab}$ \\
\hline \multirow[t]{3}{*}{ BA } & 0.3 & $5.0 d$ & $0 d$ & $70.0 \mathrm{~b}$ \\
\hline & 1.0 & $60.0 \mathrm{ab}$ & $10.0 \mathrm{~cd}$ & $35.0 \mathrm{c}$ \\
\hline & 3.0 & $30.0 \mathrm{bc}$ & $5.0 \mathrm{~cd}$ & $10.0 \mathrm{~cd}$ \\
\hline \multirow[t]{3}{*}{ Kinetin } & 0.3 & $0 d$ & $0 d$ & $100.0 \mathrm{a}$ \\
\hline & 1.0 & $0 d$ & $0 d$ & $90.0 \mathrm{ab}$ \\
\hline & 3.0 & $0 d$ & $0 d$ & $95.0 \mathrm{ab}$ \\
\hline \multirow[t]{3}{*}{ TDZ } & 0.3 & $42.5 \mathrm{ab}$ & $15.0 \mathrm{bcd}$ & $5.0 \mathrm{~d}$ \\
\hline & 1.0 & $75.0 \mathrm{a}$ & $20.0 \mathrm{abc}$ & $20.0 \mathrm{~cd}$ \\
\hline & 3.0 & $90.0 \mathrm{a}$ & $35.0 \mathrm{a}$ & $15.0 \mathrm{~cd}$ \\
\hline \multirow[t]{3}{*}{ Zeatin } & 0.3 & $70.0 \mathrm{a}$ & $5.0 \mathrm{~cd}$ & $10.0 \mathrm{~cd}$ \\
\hline & 1.0 & $90.0 \mathrm{a}$ & $20.0 \mathrm{abc}$ & $10.0 \mathrm{~cd}$ \\
\hline & 3.0 & $70.0 \mathrm{a}$ & $30.0 \mathrm{ab}$ & $10.0 \mathrm{~cd}$ \\
\hline
\end{tabular}

Means within a column followed by the same letter are not significantly different according Duncan's multiple range test at $\mathrm{p} \leq 0.05$ (Duncan 1955 )

Chen and Chang 2000). However, 2,4-D showed highly inhibitory on direct somatic embryogenesis in Oncidium (Chen et al. 1999; Chen and Chang 2001), Dendrobium (Chung et al. 2005, 2007) and Phalaenopsis (Kuo et al. 2005; Gow et al. 2008). In this present study, we combined $1 \mathrm{mg} \mathrm{l}^{-1}$ 2,4-D with $0,0.3$ and $3 \mathrm{mg} \mathrm{l}^{-1}$ TDZ to test the effect on direct somatic embryogenesis. Table 3 showed that at $1 \mathrm{mg} \mathrm{l}^{-1} 2,4-\mathrm{D}$ plus $0.3 \mathrm{mg} \mathrm{l}^{-1} \mathrm{TDZ}$ and $1 \mathrm{mg} \mathrm{l}^{-1}$ 2,4-D plus $3 \mathrm{mg} \mathrm{l}^{-1}$ TDZ, 5 and $10 \%$ of explants formed somatic proembryos, respectively. However, no globular embryos were found at these two treatments and it may due to the $100 \%$ of browning percentage (Table 3 ). In addition, the leaf explants did not form callus at all of the treatments.

\section{Effect of light regime on direct somatic embryogenesis}

In previous reports, light regime was a negative factor that highly retarded the embryogenic response of leaf explants in Oncidium, Dendrobium and Phalaenopsis (Chen et al. 1999; Chung et al. 2005, 2007; Gow et al. 2009). However, in the root-derived callus culture of Oncidium 'Gower Ramsey', light regime was a crucial factor for inducing of indirect embryogenesis (Chen and Chang 2000; Wu et al. 2004). In this study, Table 4 showed that light regime highly retarded direct somatic embryogenesis and resulted in $95-100 \%$ of explants browning.
Table 3 Effects of 2,4-D plus TDZ on direct somatic embryogenesis from leaf explants of Tolumnia Louise Elmore 'Elsa', when the explants were cultured in darkness for 90 days

\begin{tabular}{lllll}
\hline $\begin{array}{l}\text { 2,4-D } \\
\left(\mathbf{m g ~ I}^{-1}\right)\end{array}$ & $\begin{array}{l}\text { TDZ } \\
\left(\mathbf{m g ~ I}^{-\mathbf{1}}\right)\end{array}$ & $\begin{array}{l}\text { \% of explants } \\
\text { with somatic } \\
\text { proembryos }\end{array}$ & $\begin{array}{l}\text { \% of explants } \\
\text { with somatic } \\
\text { globular } \\
\text { embryos }\end{array}$ & $\begin{array}{l}\text { \% of brown- } \\
\text { ing }\end{array}$ \\
\hline 0 & 0 & $0 \mathrm{a}$ & 0 & $100.0 \mathrm{a}$ \\
1 & 0 & $0 \mathrm{a}$ & 0 & $100.0 \mathrm{a}$ \\
1 & 0.3 & $5.0 \mathrm{a}$ & 0 & $100.0 \mathrm{a}$ \\
1 & 3 & $10.0 \mathrm{a}$ & 0 & $100.0 \mathrm{a}$
\end{tabular}

Means within a column followed by the same letter are not significantly different according Duncan's multiple range test at $p \leq 0.05$ (Duncan 1955)

\section{Conclusion}

This present study is the first to establish an efficient protocol for regenerating a Tolumnia orchid via direct somatic embryogenesis. It took about 4 months to obtain the regenerated plantlets with normal morphogenesis. Plant regeneration was derived from leaf cultures via an in vitro morphogenetic pathway that meristematic cells developed initially, and followed by somatic proembryos, somatic globular embryos, somatic embryos with the bipolar structure, and eventually plantlets. This protocol provided the basis for further investigation on micropropagation, in vitro 
Table 4 Effects of TDZ and zeatin on direct somatic embryogenesis from leaf explants of Tolumnia Louise Elmore 'Elsa', when the explants were cultured in light condition for 90 days

\begin{tabular}{lllll}
\hline Cytokinins & Concentration $\left(\mathbf{m g ~ l}^{-\mathbf{1}}\right)$ & $\begin{array}{l}\text { \% of explants with somatic pro- } \\
\text { embryos }\end{array}$ & $\begin{array}{l}\text { \% of explants with somatic globular } \\
\text { embryos }\end{array}$ & $\begin{array}{c}\% \text { of browning } \\
\text { Hormone-free control }\end{array}$ \\
\hline & 0 & $0 \mathrm{c}$ & 0 & $100.0 \mathrm{a}$ \\
TDZ & 1 & $10.0 \mathrm{abc}$ & 0 & $100.0 \mathrm{a}$ \\
& 3 & $5.0 \mathrm{bc}$ & 0 & $100.0 \mathrm{a}$ \\
Zeatin & 1 & $25.0 \mathrm{ab}$ & 0 & $100.0 \mathrm{a}$ \\
& 3 & $40.0 \mathrm{a}$ & 0 & $95.0 \mathrm{a}$ \\
\hline
\end{tabular}

Means within a column followed by the same letter are not significantly different according Duncan's multiple range test at $\mathrm{p} \leq 0.05$ (Duncan 1955)

morphogenesis, gene transfer or breeding programs in Tolumnia orchids.

\section{Abbreviations}

2,4-D: 2,4-dichlorophenoxyacetic acid; 2iP: N6-2-isopentenyl adenine; BA: $N^{6}$-benzyladenine; Kinetin: $N^{6}$-furfuryladenine; TDZ: 1-phenyl-3-(1,2,3-thiadiazol-5-yl)-urea; Zeatin: 6-[4-hydroxy-3-methylbut-2-enylamino]purine.

\section{Authors' contributions}

JTC and WCC conceived and designed the experiments; HJS carried out the experimental work and data collection; JTC helped in the data analysis; JTC and $\mathrm{HHC}$ wrote the manuscript; $\mathrm{HHC}$ reviewed and finalized the manuscript; WCC provided laboratory facilities and important comments. All authors read and approved the final manuscript.

\section{Author details}

${ }^{1}$ Institute of Plant and Microbial Biology, Academia Sinica, Taipei 115, Taiwan, ROC. ${ }^{2}$ Department of Life Sciences, National University of Kaohsiung, Kaohsiung 811, Taiwan, ROC. ${ }^{3}$ Department of Horticulture, National Ilan University, Yilan 260, Taiwan, ROC.

\section{Competing interests}

The authors declare that they have no competing interests.

\section{Consent for publication}

Not applicable.

Ethics approval and consent to participate

Not applicable.

\section{Funding}

No funding was received.

\section{Publisher's Note}

Springer Nature remains neutral with regard to jurisdictional claims in published maps and institutional affiliations.

Received: 26 March 2017 Accepted: 16 January 2018

Published online: 22 January 2018

\section{References}

Chen JT, Chang WC (2000) Efficient plant regeneration through somatic embryogenesis from callus cultures of Oncidium (Orchidaceae). Plant Sci 160:87-93

Chen JT, Chang WC (2001) Effects of auxins and cytokinins on direct somatic embryogenesis in Oncidium 'Gower Ramsey'. Plant Growth Regul 34:229-232

Chen JT, Chang WC (2002) Effects of tissue culture conditions and explant characteristics on direct somatic embryogenesis in Oncidium 'Gower Ramsey.' Plant Cell Tiss Org 69:41-44
Chen JT, Chang WC (2006) Direct somatic embryogenesis and plant regeneration from leaf explants of Phalaenopsis amabilis. Biol Plant 50:169-173

Chen JT, Chang C, Chang WC (1999) Direct somatic embryogenesis on leaf explants of Oncidium 'Gower Ramsey' and subsequent plant regeneration. Plant Cell Rep 19:143-149

Chung HH, Chen JT, Chang WC (2005) Cytokinins induce direct somatic embryogenesis of Dendrobium Chiengmai Pink and subsequent plant regeneration. Vitro Cell Dev Biol Plant 2005(41):765-769

Chung HH, Chen JT, Chang WC (2007) Plant regeneration through direct somatic embryogenesis from leaf explants of Dendrobium. Biol Plant 51:346-350

Compton ME (1994) Statistical methods suitable for the analysis of plant tissue culture data. Plant Cell Tissue Org 37:217-242

Dawes CJ (1971) Biological techniques in electron microscopy. Barnes \& Noble, New York

Duncan DB (1955) Multiple range and multiple F test. Biometrics 11:1-42

Feng JH, Chen JT (2014) A novel in vitro protocol for inducing direct somatic embryogenesis in Phalaenopsis aphrodite without taking explants. Sci World J. Article ID 263642: 7. https://doi.org/10.1155/2014/263642

Gow WP, Chen JT, Chang WC (2008) Influence of growth regulators on direct embryo formation from leaf explants of Phalaenopsis orchids. Acta Physiol Plant 30:507-512

Gow WP, Chen JT, Chang WC (2009) Effects of genotype, light regime, explant position and orientation on direct embryo formation from leaf explants of Phalaenopsis orchids. Acta Physiol Plant 31:363-369

Gow WP, Chen JT, Chang WC (2010) Enhancement of direct somatic embryogenesis and plantlet growth from leaf explants of Phalaenopsis by adjusting culture period and explant length. Acta Physiol Plant 32:621-627

Hong PI, Chen JT, Chang WC (2008a) Effects of salicylic and acetylsalicylic acid on direct somatic embryogenesis in Oncidium. J Plant Biochem Biotechnol 17:149-153

Hong PI, Chen JT, Chang WC (2008b) Promotion of direct somatic embryogenesis of Oncidium by adjusting carbon sources. Biol Plant 52:597-600

Islam SS, Bhattacharjee B (2015) Plant regeneration through somatic embryogenesis from leaf and root explants of Rhynchostylis retusa (L.) Blume. Appl Biol Res 17:158-165

Jensen WA (1962) Botanical histochemistry: principles and practice. Freeman, San Francisco

Kuo HL, Chen JT, Chang WC (2005) Efficient plant regeneration through direct somatic embryogenesis from leaf explants of Phalaenopsis 'Little Steve'. Vitro Cell Dev Biol Plant 41:453-456

Liao YK, Wu YH (2011) In vitro propagation of Platycerium bifurcatum (Cav.) C. Chr. green globular body initiation. Bot Stud 52:455-463

Mahendran G, Bai VN (2016) Direct somatic embryogenesis of Malaxis densiflora (A. Rich.) Kuntze. J Genet Eng Biotechnol 14:77-81

Moradi S, Dianati Daylami S, Arab M, Vahdati K (2017) Direct somatic embryogenesis in Epipactis veratrifolia, a temperate terrestrial orchid. J Hortic Sci Biotechnol 92:88-97

Murashige T, Skoog F (1962) A revised medium for rapid growth and bioassays with tobacco tissue cultures. Physiol Plant 15:495-497

Su YJ, Chen JT, Chang WC (2006) Efficient and repetitive production of leafderived somatic embryos of Oncidium. Biol Plant 50:107-110

Wu IF, Chen JT, Chang WC (2004) Effects of auxins and cytokinins on embryo formation from root-derived callus of Oncidium 'Gower Ramsey'. Plant Cell Tissue Org 77:107-109 